Abstract

\title{
Antiproliferative Effect of Methanolic Extract of Linum arboreum on A549 Cells ${ }^{\dagger}$
}

\author{
Ozgur Vatan *, Ozer Yılmaz, Huzeyfe Huriyet, Tolga Cavas and Nilufer Cinkılıç \\ Department of Biology, Science and Art Faculty, Uludag University, Bursa 16059, Turkey; \\ ozery@uludag.edu.tr (O.Y.); huzobio@gmail.com (H.H.); tcavas@gmail.com (T.C.); \\ aydemirn@uludağ.edu.tr (N.C.) \\ * Correspondence: ovatan@uludag.edu.tr; Tel.: +053-5359-7062 \\ + Presented at the 2nd International Conference on Natural Products for Cancer Prevention and Therapy, \\ Kayseri, Turkey, 8-11 November, 2017.
}

Published: 14 November 2017

\begin{abstract}
Many anticancer drugs in clinical use are natural product derived from natural sources. Today, investigations of anti cancer effect of different natural products are increase. The aimed of the current study was to investigate possible antiproliferative effects of methanolic extract of Linum arboreum leaves (MELAL) and fruits (MELAF). Linumarboreum is a plant species that member of Linacea efamily. We evaluated the antiproliferative effect of MELAL and MELAF on human lung carcinomacells A549 by XTT assay. Cells exposed different concentration of MELAL and MELAF $(0.1-2000 \mu \mathrm{g} / \mathrm{mL})$ for $24 \mathrm{~h}$. IC50 value was determined $0.771 \pm 0.043 \mu \mathrm{g} / \mathrm{mL}$ of MELAL and IC50 value was determined $1.456 \pm 0.995 \mu \mathrm{g} / \mathrm{mL}$ of MELAF. MELAL has shown higher antiproliferative activity compare with MELAF. Alsoboth of MELAL and MELAF have higher antiproliferative activity with low IC50 values in compared cisplatin. Especially MELAL has shown strong anticancer activity with low IC50 value. Nevertheless, anti cancer activity of MELAL should be supported by further studies.
\end{abstract}

Keywords: Linumarboreum; XTT; A549

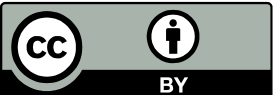

(C) 2017 by the authors. Licensee MDPI, Basel, Switzerland. This article is an open access article distributed under the terms and conditions of the Creative Commons Attribution (CC BY) license (http://creativecommons.org/licenses/by/4.0/). 